\title{
Use of Ecosystem Module based on Science, Environment, Technology, and Society, with Islamic Values
}

\author{
Sri Mulyani Endang Susilowati ${ }^{1 *}$ and Iskandar Mubarok ${ }^{2}$ \\ 'Department of Biology, FMIPA, Universitas Negeri Semarang, Indonesia; \\ nanik_es@mail.unnes.ac.id \\ ${ }^{2}$ Madrasah Aliyah Negeri Kalimukti, Cirebon, Indonesia; \\ iskandarlosari@yahoo.co.id
}

\begin{abstract}
Objectives: This study aimed to test the effectiveness of the use of learning modules of the ecosystem, based Science, Environment, Technology, and Society (SETS) with Islamic values toward the cognitive learning outcomes of students of MAN (Madrasah Aliyah Negeri) Kalimukti Cirebon. Methods: Islamic values, in this case, include the value system and moral arguments related to the theory of religion, which is integrated with the verses of Al-Quran and Al-Hadith. This study was conducted with a pretest-posttest design with control groups. The population was students of the ten grade of MAN Kalimukti consisting of four classes. The sampling technique using cluster random sampling, and the derived class for experimental is the A class and the control is B class. Findings: The results of this study indicated that the learning module of ecosystem-based SETS with Islamic values that were used can increase the students' cognitive learning outcomes. This was clearly shown by a significant difference between the posttest results of a control class and experimental class. Application: Therefore, the module based SETS with Islamic values effectively to improve the learning outcomes of Biology, students of MAN Kalimukti.
\end{abstract}

Keywords: Ecosystem Module, Islamic Value, SETS

\section{Introduction}

Along with the development and advancement of education, teachers were required to be able to organize a sort of active, creative, effective and attractive learning activities to create a memorable learning experience for learners. One of the factors that can support the success of the learning process was the selection of appropriate teaching materials. The use of modules effectively makes the students more active, creative and reflective ${ }^{1}$. Active and creative learners will make the learning activities not monotonously "dominated by the teacher".

Topics in Biology were not only learned about a bunch of knowledge, but it was also dynamic and practical. According to ${ }^{2}$ teaching process with SETSvision (Science, Environment, Technology, and Society) was able to give an understanding to students about the role of science, environment, technology, and society, so students were expected to make use of their knowledge in daily activities. At the same time, the teaching process with SETS-vision is also able to make learners aware of how technology affects the rate of progression of science as well as the impact on the environment and society.

In Islam, there was a concept of unity between science, faith, and charity. According to ${ }^{-3}$ the study of Biology in nuanced by the value which can be given explicitly or implicitly. Biology lesson is a way to learn science with the value system and moral arguments related to religious theory,

*Author for correspondence 
as integrated with the verses of Al-Quran and the relevant $\mathrm{Al}$-Hadith. Some examples from the Al-Quran are explaining a lot about the ecosystem ${ }^{4}$. In Al-Quran, particularly in the Surah of Al-Baqoroh (2) verse 30, stated that Allah SWT made man as caliph (leader) of the earth. It brought the meaning that Allah entrusted to man as the leader on the earth to manage and maintain a good balance in the earth and avoid destruction in the earth. This Surah is one of the examples that $\mathrm{Al}$-Quran can be used to integrate science and religion. The study of Biology in nuanced by the value in an implicit way is to figure out the system and moral value contained in teaching materials, associated with the rules in the society to be analogized to human life.

The initial investigations were conducted based on the first observation from Madrasah Aliyah Negeri (MAN) Kalimukti, Cirebon. Some of them were: MAN Kalimukti is the newly MAN in Cirebon regency, they use curriculum 2006 or commonly named KTSP (Kurikulum Tingkat Satuan Pendidikan), the lack of facilities and infrastructures, inadequate books and references for teachers and learners, unavailability of the module with SETS-vision, teaching-learning activities were still using teachercentered learning. And the Biology lessons were still within the scope of cognitive achievement and have not reached the attitude achievement and psychomotor, and also there is still a dichotomy between religion and biological knowledge that can affect students' learning motivation. Based on the results of preliminary observations in MAN Kalimukti Cirebon, extensive experiments need to be carried out by implementing learning modules SETS-vision with Islamic values to increase a thorough understanding of natural phenomena that they have learned in the nuance of religion.

\section{Methods}

The research was held in MAN Kalimukti, Cirebon. This study used the experimental method with pretest-posttest control group design. The population was the first semester of tenth graders which consisted of 10-A, 10-B, 10-C, and $10-\mathrm{D}$ classes. The sampling technique used cluster random sampling.

The selected groups were: ten-A class as test class and ten-B class as control. As the independent variable was 'learning' which used modules SETS-vision with Islamic values and the dependent variable was 'student cognitive learning outcome. The design of the research could be shown in Figure 1.

\begin{tabular}{|llll|}
\hline $\mathrm{R}$ & $\mathrm{E}: \mathrm{O}_{1}$ & $\mathrm{X}$ & $\mathrm{O}_{2}$ \\
$\mathrm{R}$ & $\mathrm{C}: \mathrm{O}_{1}$ & & $\mathrm{O}_{2}$ \\
\hline
\end{tabular}

Information:

$$
\begin{aligned}
& \mathrm{O}_{1}=\text { pre-test of experiment and control class } \\
& \mathrm{O}_{2}=\text { post-test of experiment and control dass } \\
& R=\text { Random sampling } \\
& X=\text { learning use modules SETS-vision with Islamic values } \\
& \mathrm{E}=\text { Experiment class } \\
& \mathrm{C}=\text { Control class }
\end{aligned}
$$

Figure 1. Experimental design.

Before the learning starts, a pre-test was conducted in the experimental (test) and control classes to find out the initial knowledge of the students. Pretest data were analyzed for normality by using chi-square and homogeneity test by using Bartlett test ${ }^{5}$. If the data were normally distributed and homogeneous then the analysis was continued by t-test to determine the initial condition of the experimental and control class. If $t_{\text {arithmetic }}<t_{\text {table }}$ with $\alpha=0.05$, means there is no significant difference between students' cognitive ability of experimental class and class control. After that is done the learning process by using ecosystem module that is prepared in experiment class and control class use textbook usually used before. At the end of the learning process, posttest is held. Posttest data were analyzed for normality and homogeneity and then continued $\mathrm{t}$-test. If $\mathrm{t}_{\text {arithmetic }}>\mathrm{t}_{\text {table }}$ with $\alpha=0.05$, means there is a significant difference between the experimental and the control class. Conversely, if $t_{\text {arithmetic }}<t_{\text {table }}$ means there is no significant difference between the learning outcomes of students of the experimental class and the control.

\section{Results and Discussions}

The homogeneity of the experimental class and the control class was tested using the Bartlett test (Sudjana, 2005). Homogeneity test results of the daily examination tested with Barlett's test for X-1, X-2, X-3, and X-4 was $\chi^{2}=1.607$. If $\alpha=0.05$ from the distribution table of chi-quadrat with $\mathrm{df}=3$, we obtained $\chi_{0.95(3)}^{2}=3.182$. Therefore, $\chi^{2}=1.607$ $\leq 3.182$, so the hypothesis $H_{0}: \sigma_{1}^{2}=\sigma_{2}^{2}=\sigma_{3}^{2}=\sigma_{4}^{2}$ was accepted for the real standard of 0.05 . It shows that all of the four classes were homogeny.

Before conducting the experiment, a module readability test was carried out. The module readability score with student respondents is 4.36 and with the teacher respondents the score of 4.43 can both be categorized as "very good". The module readability includes the truth of the concept, 
the depth of the material, linguistics, SETS and the concepts of Islamic values, presentations, and media.

To find out the effectiveness of the module (learning material), the results of the experimental class of post-test using the SETS-vision module with Islamic values was considered. The posttest results of the experimental class were compared with the results of the posttest of the control class whose learning used textbooks at school.

The results of the pretest and posttest from the control class and the experimental class were tested for normality and homogeneity, as a requirement for parametric statistical tests, presented in Tables 1 and 2. The pre-test and post test results of control and experimental class were distributed into normal and homogenous, because of the sig $>0.05$. It showed that the initial condition of both classes before the treatment had the same ability. Based on the test results it can be concluded that the data is normally distributed and homogeneous. Furthermore, the $\mathrm{t}$-test was conducted to find out whether or not there were differences in post test results between the experimental class and the control class. The results of the t-test are presented in Table 3.
The results of the t-test from the results of the pre-test of the experimental class and the control class showed that there was no difference between them because the p-value $>$ 0.05 or $t$ counted $<\mathrm{t}$ table. This means that there is no difference between the cognitive abilities of the experimental class students with control class students. While the results of the $\mathrm{t}$-test on the post test are p-value $<0.05$ or $t_{\text {count }}>$ $\mathrm{t}_{\text {table }}$. The results show that there is a significant difference between the results of the post test of the experimental class and the control class. This difference occurs because of the different treatments between the experimental class and the control class. The experimental class uses the SETvision module with Islamic values while the control class uses textbooks available at the school.

The completeness of the minimum criterion of classical learning between control and experimental class can be seen in Tables 4 and 5 . We can conclude that before the treatment (pre-test) on control and experimental classes, both of the classes have not reached the minimum score criterion. About $80 \%$ of the students have not reached minimum criterion $(\mathrm{KKM}) \geq 70$. This happens because during this time students are less interested in biology. Students

Table 1. Normality of pretest and posttest results of control and experimental class with one-sample Kolmogorov-Smirnov

\begin{tabular}{|c|c|c|c|c|c|c|c|}
\hline $\begin{array}{c}\text { Cognitive } \\
\text { Learning }\end{array}$ & Class & N & Mean & SD & $\begin{array}{c}\text { Asymp. Sig } \\
\text { (2-tailed) }\end{array}$ & $\boldsymbol{\alpha}$ & Conclusion \\
\hline \multirow{2}{*}{ Pretest } & Control & 36 & 50.19 & 12.41 & 0.48 & 0.05 & Normal \\
\cline { 2 - 6 } & Experimental & 36 & 45.00 & & & \multirow{2}{*}{ Normal } \\
\cline { 2 - 7 } Posttest & Control & 36 & 63.61 & 12.96 & 0.07 & & \\
\cline { 2 - 5 } & Experimental & 36 & 78.61 & & & & \\
\hline
\end{tabular}

Table 2. Test homogeneity pretest and posttest in experimental and control class using Levene's Test

\begin{tabular}{|c|c|c|c|c|c|c|c|}
\hline \multirow{2}{*}{$\begin{array}{c}\text { Cognitive } \\
\text { Learning }\end{array}$} & Class & \multicolumn{2}{|c|}{ Score } & Mean & SD & \multirow{2}{*}{$\begin{array}{c}\text { Homogeneity } \\
\text { (Levene's Test) }\end{array}$} & Conclusion \\
\cline { 3 - 5 } & & Max & Min & & & \multirow{2}{*}{ Homogen } \\
\hline \multirow{2}{*}{ Pretest } & Control & 73.33 & 30.00 & 50.19 & 1.06 & \\
\cline { 2 - 5 } & Experimental & 73.33 & 20.00 & 45.00 & 1.37 & & Homogen \\
\hline \multirow{2}{*}{ Posttest } & Control & 80.00 & 43.33 & 63.61 & 1.09 & 0.13 & \\
\cline { 2 - 5 } & Experimental & 100.00 & 53.33 & 78.61 & 1.03 & & \\
\hline
\end{tabular}

Table 3. T-test of pretest and posttest results

\begin{tabular}{|c|c|c|c|c|c|c|}
\hline Cognitive Learning & Class & Mean & $\mathrm{T}_{\text {count }}$ & $\mathrm{T}_{\text {table }}$ & p-value & Conclusion \\
\hline \multirow{2}{*}{ Prettest } & Control & 50.19 & 1.80 & 1.99 & 0.08 & $\mathrm{H}_{0}$ accepted \\
\cline { 2 - 5 } & Experimental & 45.00 & & & & \\
\hline \multirow{2}{*}{ Postest } & Control & 63.61 & 5.99 & 1.99 & 0.00 & $\mathrm{H}_{0}$ denied \\
\cline { 2 - 6 } & Experimental & 78.61 & & & & \\
\hline
\end{tabular}


feel more important religious lessons to be learned rather than biology. From Table 5, we can see that after the treatment (post test) experimental class has reached the minimum score criterion. As much as $81 \%$ of the students of experimental class or similar to 29 students have passed the minimum score criterion. In the control class, only $47 \%$ of the students or similar to 17 students have passed the minimum score criterion. It means that classical completeness has not been reached. This occurs because the module is used to contain Islamic values that open students' thinking that the study of biology as a general knowledge is as important as religion lessons they learned over the years. They feel that the subject matter of biology can be applied to daily life.

According to ${ }^{6}$, the module was teaching material which was arranged systematically with the choice of diction that was easy to be understood by students, in accordance with the level of knowledge and their age, so that they can learn independently with minimal assistance from the facilitator. Biology learning module with SETS-vision and Islamic values was developed and designed to make the learning process centered on students. Student-centered learning approach brings students to do various activities that are relevant to the materials and puts the teacher as the facilitator in the classroom. Students will not only learn about the theory, but also directly practice the concepts which were being learned so that the students were aware that the knowledge they get was not just simply learned and memorized, but it can also be applied in daily life ${ }^{\mathrm{Z}}$.

Based on the validity results from biology experts, SETS and religion experts, and learning media experts, the validity level which is developed with score 4.31 belongs into "valid" category. It was assessed in some aspects, that is suitable for the contents, the presentation, linguistics, and also SETS and Islamic values aspects. It explained that the developed learning module was able to: (a) help students to learn independently; (b) make teachers have lesson plans that can be responded to optimally by students; (c) provide a complete learning materials and give students opportunities to learn independently; and (d) monitor students' activities in the classroom ${ }^{\circ}$.

The small-scale trial was held in Class No. 10 from the group no. 2 which consisted of 35 students and a Biology teacher. The next procedure was to give all of the 35 students learning module which has been developed to be learned at home and in the classroom during the teaching-learning process. In the last meeting, students were given legibility questionnaire sheets and comments about the developed Biology module. From the 35 students, we obtained a "very good" response to the developed module. It can be seen from the average score of students responses with the score 4.36 and can be put into "very good" category. Legibility score from teacher reached the average point of 4.43 which is also put into "very good" category. From the legibility results, we can draw a conclusion that the developed Biology module is qualified with the aspects and characteristics of the appropriate module which consist of self-instruction, self-contained, stand-alone, adaptive, and user-friendly.

Learning concepts according to constructivist learning theory was a new understanding which is constructed independently by students based on the knowledge that has been acquired previously. Constructivism in the learning process is based on the fact that each individual has the ability to reconstruct the experience or knowledge which has been owned. Learning module with SETS-vision and

Table 4. Percentage of cognitive learning results of control and experimental class (pretest)

\begin{tabular}{|c|c|c|c|c|c|c|c|c|c|}
\hline \multirow[t]{2}{*}{$\begin{array}{l}\text { Cognitive } \\
\text { Learning }\end{array}$} & \multirow[t]{2}{*}{$\begin{array}{c}\text { Amount of } \\
\text { Students }\end{array}$} & \multirow[t]{2}{*}{$\begin{array}{l}\text { Sum of } \\
\text { Score }\end{array}$} & \multirow[t]{2}{*}{ Average } & \multirow[t]{2}{*}{ Completeness } & \multirow[t]{2}{*}{$\%$} & \multirow[t]{2}{*}{$\begin{array}{c}\text { Not } \\
\text { Complete }\end{array}$} & \multirow[t]{2}{*}{$\%$} & \multicolumn{2}{|c|}{$\begin{array}{c}\text { Class } \\
\text { Completeness }\end{array}$} \\
\hline & & & & & & & & Yes & No \\
\hline Control & 36 & 1806.67 & 50.19 & 4 & 11 & 32 & 89 & & $\sqrt{ }$ \\
\hline Experimental & 36 & 1620.00 & 45.00 & 3 & 8 & 33 & 92 & & $\sqrt{ }$ \\
\hline
\end{tabular}

Table 5. Percentage of cognitive learning results of control and experimental class (posttest)

\begin{tabular}{|c|c|c|c|c|c|c|c|c|c|}
\hline $\begin{array}{c}\text { Cognitive } \\
\text { Learning }\end{array}$ & $\begin{array}{c}\text { Amount of } \\
\text { Students }\end{array}$ & $\begin{array}{c}\text { Sum of } \\
\text { Score }\end{array}$ & Average & Completeness & $\%$ & \multicolumn{2}{|c|}{$\begin{array}{c}\text { Not } \\
\text { Complete }\end{array}$} & \multicolumn{2}{|c|}{$\begin{array}{c}\text { Class } \\
\text { Completeness }\end{array}$} \\
\hline Control & 36 & 2290.00 & 63.61 & 17 & 47 & 19 & 53 & Yes & No \\
\hline Experimental & 36 & 2830.00 & 78.61 & 29 & 81 & 7 & 19 & $\sqrt{ }$ & \\
\hline
\end{tabular}


Islamic value can be used as an instrument to prepare students to construct their knowledge. Teacher takes a role as a facilitator or the creator of learning conditions which allows students to actively gain information, to assimilate and adapt the information independently, and to construct the acquired information into a new understanding. The use of the module in the teaching-learning process has been proven to help students in developing their understanding so they can reach the minimum score criterion, to engage students to be active in the learning process, and to shape them to always create their own understanding independently in the learning process 9 .

The mastery of learning of control class has not reached the minimum criterion; this cannot be separated from the use of textbook during the teaching-learning process. The use of textbook during teaching-learning process was less effective to help students to understand the material of ecosystem so they cannot answer the questions that have been given correctly. $\operatorname{In}^{5}$ explained that teaching instruments are selected based on the criterion that the instruments can support the materials which are taught, in accordance with the purpose of teaching and the level of students' thinking. The mastery of classical learning of experimental class with the percentage of $81 \%$ and fulfilled the indicators was a positive result. The implementation of the module with SETS-vision and Islamic values effectively helps students to apply the concepts to solve the problem of the ecosystem in the form of post test assignments.

The impression that was shaped from learning process with SETS-vision which gives a positive impact on students' learning results $\frac{10,11}{1}$ shows that the learning process with SETS-vision can increase the learning results. The study of Biology does not always work independently; it can also be integrated with Islamic values, like the results of Rochman's research (2010) which stated that the study of general science integrated with religious values can be applied in the learning process.

\section{Conclusion}

The use of ecosystem module with SETS-vision and Islamic values in MAN Kalimukti, Cirebon, reached the effective criterion, because of the significant differences in the average score of cognitive learning. The difference of percentage classical result between control and experimental classes was percentage is $47 \%$ and $81 \%$.

The research suggests that biology teachers of Madrasah Aliyah should incorporate not only ecosystem but also Islamic values into the biological material so that the students of Madrasah Aliyah are more interested in studying Biological Sciences.

\section{Acknowledgement}

The author thanks the Head of Madrasah Aliyah Negeri Kalimukti, Cirebon; which has given permission to conduct this study, also to Biology teacher and students of the class tenth that has helped make this research accomplished.

\section{References}

1. Alias N, Siraj S. Design and development of physics module based on learning style and appropriate technology by employing Isman Instructional Design Model. The Turkish Online Journal of Educational Technology. 2012; 11(4):84-93

2. Binadja A. Hakikat dan tujuan Pendidikan SETS (Science Environment, Technology, and Society) Dalam Kontek Kehidupan dan Pendidikan yang Ada. Makalah Seminar Lokakarya pendidikan SETS; 1999.

3. Yudianto, Suroso Adi. Pembelajaran sains biologi menggunakan nuansa nilai untuk meningkatkan hasil belajar dan sikap siswa. Jurnal Inovasi Pendidikan. 2009; 10(1):1-15.

4. Suhendra A. Kontestasi Identitas Melalui Pergeseran Interpretasi hijab dan jilbab dalam 1 Quran. Jurnal Studi Gender. 2013; 6 (1).

5. Sudjana. Metode Statistika. Edisi 6. Bandung: Tarsito; 2005.

6. Prastowo A. Panduan kreatif membuat bahan ajar inovatif. Yogyakarta: Diva Press; 2014. PMid:25057524

7. Hunde $A B$, Tegegne KM. Qualitative exploration on the application of student-centered learning in mathematics and natural sciences: The case of selected general secondary schools in Jimma, Ethiopia. Ethiopia Journal of Education and Science. 2010; 6(1):41-58.

8. Indriyanti NY, Susilowati E. Pengembangan Modul. Surakarta: UNS; 2010.

9. Mak AS, Arthur G. Benefits of self-paced learning module for teaching quantitative methods in environmental science. International Journal of Science Education. 1997; 19(7):835-48. https://doi.org/10.1080/0950069970190707

10. Binadja A, Wardani S, Nugroho S. Keberkesanan pembelajaran materi ikatan bervisi SETS (Science Environment Technology and Society) pada hasil belajar peserta didik. Jurnal Inovasi Pendidikan. 2008; 2(2):256-62.

11. Esmiyati E. Pengembangan modul IPA terpadu bervisi SETS (Science Environment Technology and Society) pada tema ekosistem. Unnes Science Education Journal. 2013; 2(1):180-7. 